\title{
Correction to: Aging in Northeast Thai Communities: Who are and Will Be Supporting the Aged?
}

\author{
Hirofumi Ando ${ }^{1} \cdot$ Pennee Kantavong ${ }^{1} \cdot$ Rikiya Matsukura $^{2}$. \\ Narong Kiettikunwong ${ }^{1}$
}

๑) Springer Science+Business Media, LLC, part of Springer Nature 2022

\section{Correction to: Ageing International https://doi.org/10.1007/s12126-022-09484-8}

The original article has been corrected. It contains error specifically forth/corresponding author last name is misspelled. The correct one is "Kiettikunwong".

Publisher's Note Springer Nature remains neutral with regard to jurisdictional claims in published maps and institutional affiliations.

The original article can be found online at https://doi.org/10.1007/s12126-022-09484-8.

Narong Kiettikunwong

naroki@kku.ac.th

1 College of Local Administration, Khon Kaen University, Khon Kaen, Thailand

2 College of Economics, Nihon University, Tokyo, Japan 